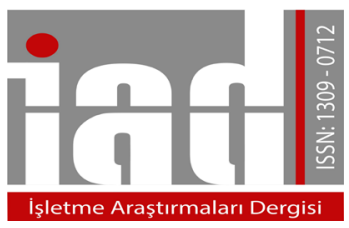

\author{
İşletme Araştırmaları Dergisi \\ Journal of Business Research-Turk \\ 10/4 (2018) 229-245
}

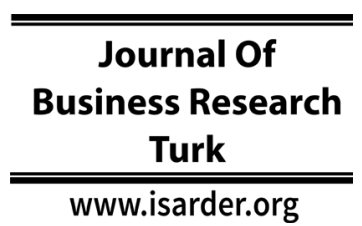

$\underline{\text { Research Article }}$

\title{
Analyzing the Attitudes of Turkish Shipowning Companies Towards Green Shipping Application Aiming Sustainable Transportation ${ }^{1}$
}

\author{
İlke Sezin Ayaz \\ Dokuz Eylül University \\ Maritime Faculty, Tinaztepe Campus \\ 35160 Buca- Izmir, Turkey. \\ orcid.org/0000-0002-7053-3940 \\ ilke.ayaz@deu.edu.tr
}

\author{
İsmail Bilge Çetin \\ Dokuz Eylül University \\ Maritime Faculty, Tinaztepe Campus \\ 35160 Buca-Izmir, Turkey. \\ orcid.org/0000-0002-4951-426X \\ ismail.cetin@deu.edu.tr
}

\begin{abstract}
Maritime transport is the basis of world trade and globalization. Although maritime transportation has the lowest negative impact on the environment, it has still effecting the environment through shipping emissions, oil spills, solid wastes, sewage and noise pollution from the ships. Therefore, maritime transport activities are becoming one of the most important topics on sustainability debate. This study aims to analyze the attitudes of Turkish shipowning companies towards green shipping applications including a thorough review of the literature and implementing a Delphi research. At the end of the third round of Delphi research, the respondents have reached a consensus on such domains as "company policy and procedures", "shipping equipment", "shipper cooperation", "shipping design and compliance", as well as the reasons for and the benefits of adapting and implementing green shipping practices. They, however, have not reached concensus on some statements related to "shipping documents", "shipping materials" and difficulties of "implementing green shipping applications".
\end{abstract}

Keywords: Maritime Transport, Sustainability, Green Shipping Applications, Environmental Problems, Delphi Research

Received 18 May 2018; Received in revised from 11 November 2018; Accepted 20

November 2018

\section{Introduction}

Maritime transport is the basis of world commerce and globalization since the global economic development and international maritime trade are closely related (Bijwaard and Knapp, 2009; Casaca et al., 2011). During its long history dating back to $1700 \mathrm{BC}$, maritime transport includes carriage of passengers and goods from

\footnotetext{
1 This study was produced from the master thesis titled as "The Attitudes of Managers in Turkish Shipowning Companies towards Green Shipping Applications", which was completed by İlke Sezin AYAZ under the supervision of Assoc.Prof. Dr. İsmail Bilge ÇETIN.
}

\section{Suggested Citation:}

Ayaz, İ.S., Çetin, İ.B. (2018). Analyzing the Attitudes of Turkish Shipowning Companies Towards Green Shipping Application Aiming Sustainable Transportation, Journal of Business Researh-Turk, 10 (4), 229245. 
manufacturing areas to consumption locations and it contributes to the economic development (Lun et al., 2013: 320).

With the growth of international seaborne trade and transport demand, maritime transport activities are becoming one of the most important topics on sustainability debate. In contrast with other modes of transport, maritime transport has had a partially green view, but still maritime sector is a great participator to global ecologic problems. Shipping emissions, oil spills, solid wastes, sewage pollution, and noise pollution from ships are main environmental problems brought about by maritime transport. In parallel with growing importance of maritime transport and their environmental impacts, many maritime companies have begun to react to environmental apprehensions by making greener their operations. These efforts are named as "green shipping practices or applications" in the literature.

Green shipping practices can be formalized in different manners such as view of natural science, technological progress and business management and it includes handling and distributing shipments in sustainable perspective, taking account of environmental matters and involves the coordination and cross-functional cooperation with several parties along the transport chain (Lai et al., 2013: 220). Nowadays, for cleaner and greener operations, the shipping industry facing increased force to follow more stringent environmental regulations. Especially IMO regulations which are also confirmed by Turkey, make arrangements and set rules concerning with environmental problems based on maritime transport. Adoption of green shipping practices (GSP) is progressively well-liked by shipping companies because of these reasons (Lam and Lai, 2015).

In the light of these developments, the main aim of the study is to examine with Delphi research the attitudes of Turkish shipowning companies towards green shipping applications. Main objectives of the study are to scrutinize the opinions of Turkish ship owners concerning dimensions of green shipping practices and reveal the reasons for as well as the benefits and/or difficulties of adopting and implementing them. A thorough literature review has revealed the lack of theoretical attention to the green shipping concept. This situation motived us to further study on why or why not Turkish shipping firms undertake green shipping practices and to learn their attitudes towards environmental awareness. Section 2 of the research summarizes theoretical background related to sustainable shipping and green shipping concepts. Section 3 includes methodological matters related to a Delphi research of attitudes of top managers in Turkish shipping firms towards green shipping applications. In the conclusion section, discussion with literature, significance of results, limitations and suggestions for future researches are involved.

\section{Sustainable Shipping and Green Shipping Applications}

The growth and progress of the global economy are closely relevant with the commercial shipping industry (Bijwaard and Knapp, 2009; Casaca et al., 2011). Shipping activities are necessary for supporting economic relations between countries and various geographical areas and include all activities between key actors of transport chain (Lun and Marlow, 2011; Zhang et al., 2011).

In addition to importance of shipping industry, there have been growing worries related to the environmental effects and problems such as greenhouse gas emissions, noise pollution, ballast water and oil spills, marine biodiversity problems arising from 
shipping activities in the international trade. The shipping industry is now facing increased force to follow more compeller environmental regulations to become cleaner and greener in their operations (Chang and Danao, 2017). For this reason, a concept of a sustainable maritime transport system includes economic, environmental and sociocultural elements of sustainable development and all aspects of the life-cycle of vessel from design to construction and from operation to disposal and requires correctlyorganised governances that collaborate globally and encourage accordance with international standards, supported by institutions with appropriate technical specialization, such as classification societies acting as recognized organizations, getting more important to introduce a flawless and dependable service in the most productive way (IMO, 2013). With these developments, the organizational ability of green operations, in other words green capability, has transformed as a competitive urgency for various shipping firms and adoption of green shipping practices is increasingly popularized by shipping companies (Lun et al., 2015; Chang and Danao, 2017).

Green shipping practices are a kind of environmental management executions implemented by shipping companies with an importance on reduction of waste and resource protection in the duration of handling and distributing the cargoes. Main examples of green shipping practices are calculating the shipping routes' carbon footprint and utilizing alternative transportation tools for decreasing negative environmental aspects in administrating shipping activities (Lai et al., 2011). Green shipping practices are related with handling and distributing cargoes in sustainable way, considering environmental issues and involves the coordination and cross-functional cooperation with various parties along the transport chain. Green shipping management practices can be conceptualised in different methods such as viewpoint of natural science, technological improvement and business administration (Lai et al., 2013: 220).

The literature review illustrates that progressing researches have been carried out in recent years related to environmental sustainability in shipping but most of them concentrated on the speed reduction, fuel consumption, or new developments of energy for environmental or economic advantages of shipping firms (Mander, 2017; Ren and Lützen, 2017). With the study of Lai et al., (2011), theoretical propositions of green shipping practices are first proposed. Lai et al., (2011) suggest a structure for green shipping practices and generate diverse offerings related with shipping firm's environmental behaviours and actions. Also, Lai et al., (2011: 634-635) research the shipping firm's environmental worries and identified implementation dimensions of green shipping management concept into six groups to gain environmental and productivity interests. Shipping firms can apply this framework to determine progression fields in their operations to reach ecological efficiency. Lirn et al., (2014) identified three key factors of green shipping management capability which are greener policy, greener ships and greener suppliers.

In addition, Chiu et al., (2012) investigated the factors which influence shipping companies to implement green shipping measures. Authors identified three types of green shipping measures which include environmental protection, education on green management and ship technology improvement and also authors discovered that ship technology improvement factor has positive influence on the carriers' willingness to implement green shipping measures. Lai et al., (2013) generated a measurement scale for valuing Green Shipping Practices execution in the shipping industry. Authors 
identified a validated 30 item measurements scale for the practical implementation of shipping firms to interpret the several aspects of environmental-based shipping practices. Lun et al., (2014) examined the shipping firms' ability of green operations using an input/output approach. Authors found that shipping firms are deficient in terms of shipping cooperation and shipping equipment implementations but they realize the significance of green operations and they have already implemented Green Shipping Practices in their business practices. Lun et al., (2015) investigated the relationship between greening level of shipping operations and firm performance and found that there is a positive relation between green operations and firm performance in shipping operations and also shipping firms have adequate level related to company policy and procedure, shipping documentation, shipping materials and shipping design in compliance. Chang and Danao (2017) researched the which considerations influence shipping firms for interiorize green shipping practices. They found that shipping firms are mostly influenced by industrial norms prepared by institutionalized unions firms for interiorize green shipping practices. Customer's demand foe eco-friendly operations and firms own strategies related to create a good image are another factors that influence shipping firms. Although there are still few studies related with the subject; the importance of green shipping practices has been discussed in the literature in last years and various authors' interest to the green shipping management practices and implementations has increased day by day.

\section{Methodology}

To analyse the attitudes of Turkish shipowning companies towards green shipping applications, Delphi method was used in this study.

The Delphi technique which is a fairly wide range of uses includes collecting data from respondents within their profession area. With the aim of reaching unanimity related to specific real-world subject, Delphi technique planned as group communication process. The Delphi process has been used in so many areas of researches for example program planning, needs analysis, policy setting, and resource utilisation to work up alternatives, discover or disclose underlying supposes, as well as associate jurisdictions on a subject including a wide variety of disciplines (Hsu and Sandford, 2007:1). Also, Delphi method is a technique to develop group communication and interactivity between expert groups, with the aim of estimating the existence of events or trends through repetitive procedures (Linstone and Turoff, 1975). According to Dalkey and Hermer (1963), first researchers that they have implemented the first Delphi study stated that, aim of the Delphi technique is "obtain the most reliable consensus of opinion of a group of experts." In this study, opinions of the Turkish shipowners related to green shipping applications which is a relatively new concept in the literature, were tried to be investigated. Also, concensus situation of the Turkish shipowners about the green shipping dimensions and components which are in the related literature were analysed with the third round of Delphi study.

The classical Delphi procedures generally include three rounds of survey (Keeney et al., 2011). Round 1 includes ideas on a specific subject with open-ended question to the expert panel. Process of Round 2 consists of asking panellists to rate the statements in a questionnaire in accordance with their explanations on the subject. Round 3 includes asking panellists to review the ratings in accordance with unified outcomes of Round 2. Rounds of the survey may proceed until a consensus among panellists can 
meet the necessities on some or all of the items. Sometimes Round 1 survey can be passed when the Round 2 survey questionnaire can be generated according to literature review and interviews (Ke et al., 2011; Hon et al., 2011). And also the implementation of Delphi technique has a flexible feature and, as a result, some variations can be observed. According to aim of the research and specifications of expert group, number of rounds and participants were defined. Skulmoski, Hartman, and Krahn comment that "where the group is homogeneous, a smaller sample of between ten to fifteen people may yield sufficient results." (Skulmoski et al., 2007).

It has been decided to use the Delphi method in this study due to the advantages and suitability of the subject.

\subsection{Sampling and Data Collection Process}

Sampling of the study includes top managers such as technical managers, crew managers, operation managers, administrative affairs managers and ISM managers who work on general cargo and bulk shipping firms in Turkey.

Table 1: Profile of the Respondents Included in the Study

\begin{tabular}{|c|c|c|c|c|c|}
\hline Position & Number & $\begin{array}{l}\text { Employment } \\
\text { Duration in the } \\
\text { Sector }\end{array}$ & Number & $\begin{array}{l}\text { Education } \\
\text { Status }\end{array}$ & Number \\
\hline $\begin{array}{l}\text { General Manager } \\
\text { Fleet Manager } \\
\text { Crew Manager } \\
\text { Operation Manager } \\
\text { Technical Manager } \\
\text { Human Resource } \\
\text { Manager } \\
\text { ISM Manager }\end{array}$ & $\begin{array}{l}1 \\
1 \\
2 \\
3 \\
5 \\
2 \\
1\end{array}$ & $\begin{array}{l}0-5 \text { Years } \\
6-10 \text { Years } \\
11-15 \text { Years } \\
16-20 \text { Years } \\
\text { More than } \\
20 \text { Years }\end{array}$ & $\begin{array}{l}2 \\
4 \\
3 \\
4 \\
2\end{array}$ & $\begin{array}{l}\text { Bachelor } \\
\text { Degree }\end{array}$ & 15 \\
\hline Total & 15 & Total & 15 & Total & 15 \\
\hline
\end{tabular}

In this study, judgemental sampling method was used as a tool for respondent selection. Based on this method, this study tried to reach top managers who have knowledge and experience about green shipping and environmental management. To reach the participants, Maritime Human Resources Platform (DIKAP) member list was used.

15 participants responded to the first round of Delphi which aimed to evaluate the attitudes relating to green shipping management components, implementation reasons, benefits and difficulties. In the second round of the Delphi survey, which aimed to reach a consensus on statements concerning green shipping management components, implementation reasons, benefits and difficulties, 14 participants responded to the survey. 11 participants responded to the third round Delphi survey which goaled to reach a consensus on non-consensus statements discussed in the second round.

\subsection{Development of Delphi Questionnaire Forms}

In this study, the first round Delphi survey includes four open-ended questions which aim to evaluate the attitudes of the top managers of some general cargo and bulk shipping firms in Turkey concerning green shipping applications in shipping industry.

The first question is designed to analyze the attitudes of the managers about components of green shipping applications. The second question is designed to analyze 
the opinions of the managers about adopting and implementing reasons of green shipping applications. The third and fourth questions are designed to analyze the attitudes of the managers about the benefits and the reasons for adoptive and implementing difficulties of green shipping applications.

The second round of Delphi research includes likert-based interval scale which is designed by utilizing the studies from Lun et al., (2015), Lirn et al., (2014), Lun et al., (2013), Lai et al., (2011), and the answers in the first round of Delphi survey. An interval scale including "agree", "disagree" or "unable to comment" has been used for each statement. The second round includes the responses of the respondents who participated in the first round Delphi survey, in order to reach a consensus. The third round of Delphi Research includes non-consensus statements from the second round of Delphi survey.

\subsection{Analysis of the Delphi Survey}

Various Delphi studies have used for subjective criteria or descriptive statistics for the detection of consensus and the measurement degree of consensus (von der Gracht, 2012: 1528). The APMO (The Average Percentage of Majority Opinion) method was used as a consensus measurement for the identify if a consensus has been obtained. It was defined by Kapoor (1987) as:

$$
\mathrm{APMO}=\frac{\text { Majority Agreements }+ \text { Majority Disagreements }}{\sum \text { Opinions Expressed }}
$$

In the calculation process, firstly, majority agreements and disagreements numbers has to be calculated by explicating the participants' comments "agree", "disagree" and "no comment" in percentages for each statement. Majority is primarily described as a percentage over 50\%. After that, the researcher has to sum up the majority agreements and disagreements (von der Gracht, 2012: 1530).

\subsection{Results of the First Round of the Delphi Research}

The first round of the Delphi survey covers four open ended questions which aims to evaluate the attitudes of the respondents relating to green shipping management components, implementation reasons, benefits and difficulties. All the answers of the 15 participants are classified according to the subjects in the literature and included in the second round of Delphi process.

According to the answers of the respondents related to green shipping management components, education and trainings, regular inspections, coordination between ships and company, consciousness of shipowners and employees are important statements in terms of company policy and procedures. Reducing paper consumption and guiding personnel related to this issue are important in terms of shipping documentation; selecting environmentally friendly equipment and outfits is important for shipping equipment; government and shipowners' support to the environmentally friendly shipping operations are important for shipper cooperation; reducing packaging materials and waste is important for shipping materials and energy efficiency of vessels, environmentally friendly ship designs and competency of control and disposal of waste are important statements for shipping design and compliance.

In terms of the reasons for implementing green shipping management applications, respondents stated that sea is the future of humanity and leaving better world for the future generations is main reason of implementing green shipping 
practices. And also norms and regulations and pressures of governments are another important reason for implementing green shipping practices. And lastly, respondents reported that green shipping applications have positive impact on increasing the financial and environmental performance because of the more economic sailings and durable ships.

According to the respondents, main benefits of green shipping management practices is reducing environmental problems. Efficient, eco-friendly and durable ships is another benefits of implementing green shipping management applications. And also increasing financial performance with the operational efficiency and positive effect on sustainable growth via reducing depletion of resources and contribution to healthy and safe future are another benefits according to respondents. Finally, respondents believed that green shipping applications can have positive effects on the image of the company and it can be other benefit of green shipping applications.

For the difficulties of implementing green shipping applications, respondents stated that financial problems such as existing market conditions, low freight rates, requirements of new equipment and systems and other additional costs are important barriers. Lack of education and environmental sensitivity of seafarers and employees are also difficulties for respondents. Also respondents stated that lack of government support is another difficulty for implementing green shipping applications. Governments can reduce port costs for implementing green shipping applications much easier in the low freight rates conditions. And finally, according to the respondents green shipping applications can create additional workload and requires additional time and cost.

\subsection{Results of the Second Round of the Delphi Research}

After the first round of Delphi research, the second round was implemented which includes statements from the first round and related studies in the literature. When the answers of the 14 participants are examined, APMO cut-off rate of the second round Delphi survey has been found 95,3\%. As stated by Brett and Roe (2010: 8); a statement achieved consensus when it reached $70 \%$ or more. A result of $70-79 \%$ was categorized as low consensus, consensus between 80 and $89 \%$ was categorized as medium consensus and consensus that fell between 90 and 100\% was categorized as a high consensus.

Table 2: Summary Results of Second Round of the Delphi Research

\begin{tabular}{|l|l|}
\hline Majority Agreements & 793 \\
\hline Majority Disagreements & 34 \\
\hline Total Opinion Expressed & 868 \\
\hline Average Percent of Majority Opinions & $95.3 \%$ \\
\hline Number of Statements Reaching Consensus & 57 \\
\hline $\begin{array}{l}\text { Number of Statements to be Reformulated into Delphi Round } \\
\text { Three }\end{array}$ & 5 \\
\hline Low Consensus (70-79\%) & 2 \\
\hline Medium Consensus (80-89\%) & 2 \\
\hline High Consensus (90-100\%) & 52 \\
\hline Number of Statements over 70\% Consensus & 56 \\
\hline
\end{tabular}




$$
\text { APMO }=\frac{\text { Majority Agreements }+ \text { Majority Disagreements }}{\sum \text { Opinions Expressed }} \quad 95.3=\frac{793+34}{868}
$$

Table 3: Results of the Second Round of the Delphi Research

\begin{tabular}{|c|c|c|}
\hline \multirow{2}{*}{$\begin{array}{l}\text { They must be existing for green shipping applications } \\
\text { in the shipping firms }\end{array}$} & \multicolumn{2}{|l|}{ TOTAL RESULTS } \\
\hline & Consensus & $\begin{array}{l}\text { Non } \\
\text { Consensus }\end{array}$ \\
\hline \multicolumn{3}{|l|}{ A. COMPANY POLICY AND PROCEDURES } \\
\hline $\begin{array}{l}\text { 1.Senior management must support the green shipping } \\
\text { applications. }\end{array}$ & $100 \%$ agreed & \\
\hline $\begin{array}{l}\text { 2.Mid-Level management must support the green shipping } \\
\text { applications. }\end{array}$ & $100 \%$ agreed & \\
\hline $\begin{array}{l}\text { 3.Managers' environmental awareness must be suitable for } \\
\text { green shipping applications. }\end{array}$ & $100 \%$ agreed & \\
\hline $\begin{array}{l}\text { 4.There must be a cross departmental support for the green } \\
\text { shipping applications in the shipping firms. }\end{array}$ & $100 \%$ agreed & \\
\hline $\begin{array}{l}\text { 5.Company policies must support the green shipping } \\
\text { applications. }\end{array}$ & $100 \%$ agreed & \\
\hline $\begin{array}{l}\text { 6. Company management systems must support the green } \\
\text { shipping applications. }\end{array}$ & $100 \%$ agreed & \\
\hline $\begin{array}{l}\text { 7.Education and training policies of company must support } \\
\text { the green shipping applications. }\end{array}$ & $100 \%$ agreed & \\
\hline $\begin{array}{l}\text { 8.Inspection and supervision policies of company must } \\
\text { support the green shipping applications. }\end{array}$ & $100 \%$ agreed & \\
\hline $\begin{array}{l}\text { 9. Shipping firms must release environmental report to } \\
\text { public for green shipping applications. }\end{array}$ & Agreed with $91.7 \%$ & \\
\hline \multicolumn{3}{|l|}{ B. SHIPPING DOCUMENTS } \\
\hline 1. Shipping instructions must be handled electronically. & Agreed with $90,9 \%$ & \\
\hline $\begin{array}{l}\text { 2.To reduce paper consumption, invoices must be handled } \\
\text { electronically. }\end{array}$ & & $\begin{array}{c}76.9 \% \text { (a) } \\
23.1 \% \text { (d) } \\
\text { (Third } \\
\text { Round } \\
\text { Applied) }\end{array}$ \\
\hline $\begin{array}{l}\text { 3.To reduce paper consumption, payment notifications } \\
\text { must be handled electronically. }\end{array}$ & & $\begin{array}{c}84.6 \% \text { (a) } \\
15.4 \% \text { (b) } \\
\text { (Third } \\
\text { Round } \\
\text { Applied) }\end{array}$ \\
\hline $\begin{array}{l}\text { 4.To reduce paper consumption, bill of ladings must be } \\
\text { handled electronically. }\end{array}$ & & $\begin{array}{c}53.8 \% \text { (a) } \\
46.2 \% \text { (b) } \\
\text { (Third } \\
\text { Round } \\
\text { Applied) }\end{array}$ \\
\hline $\begin{array}{l}\text { 5.To reduce paper consumption, guidelines must be } \\
\text { provided to employees. }\end{array}$ & $100 \%$ agreed & \\
\hline $\begin{array}{l}\text { 6.To reduce paper consumption, software programs must } \\
\text { be used. }\end{array}$ & $100 \%$ agreed & \\
\hline $\begin{array}{l}\text { 7. To reduce paper consumption, paper recycling facilities } \\
\text { must be improved. }\end{array}$ & $100 \%$ agreed & \\
\hline C. SHIPPING EQUIPMENTS & & \\
\hline
\end{tabular}




\begin{tabular}{|c|c|c|}
\hline $\begin{array}{l}\text { 1.Packaging units in the bulk shipping must have eco- } \\
\text { design features. }\end{array}$ & $100 \%$ agreed & \\
\hline $\begin{array}{l}\text { 2.Cooperation with equipment suppliers must be built to } \\
\text { increase environmental awareness and reduce damage to } \\
\text { the environment. }\end{array}$ & $100 \%$ agreed & \\
\hline $\begin{array}{l}\text { 3.Equipment designs must be developed for compliance } \\
\text { with environmental performance standards. }\end{array}$ & $100 \%$ agreed & \\
\hline $\begin{array}{l}\text { 4.Buyer and seller's attitudes and their environmental } \\
\text { awareness are important for equipment which are used. }\end{array}$ & $100 \%$ agreed & \\
\hline $\begin{array}{l}\text { 5.Content of the agreement between buyer and seller is } \\
\text { important for equipment which are used. }\end{array}$ & Agreed with $92.3 \%$ & \\
\hline \multicolumn{3}{|l|}{ D. SHIPPER COOPERATION } \\
\hline $\begin{array}{l}\text { 1.Shippers must play a part in eco-design of cargo handling } \\
\text { equipment. }\end{array}$ & $100 \%$ agreed & \\
\hline $\begin{array}{l}\text { 2.Shippers must play a part in environmentally friendly } \\
\text { cargo transport. }\end{array}$ & $100 \%$ agreed & \\
\hline $\begin{array}{l}\text { 3. Shippers must play a part in improving the environmental } \\
\text { performance of the shipping sector. }\end{array}$ & $100 \%$ agreed & \\
\hline $\begin{array}{l}\text { 4. Shippers must play a part in the process of green } \\
\text { distribution and supply chain. }\end{array}$ & $100 \%$ agreed & \\
\hline $\begin{array}{l}\text { 5.Financial situation of sector is important for shipper } \\
\text { cooperation. }\end{array}$ & $100 \%$ agreed & \\
\hline $\begin{array}{l}\text { 6.Shippers' environmental awareness and attitudes are } \\
\text { important for shipper cooperation. }\end{array}$ & $100 \%$ agreed & \\
\hline $\begin{array}{l}\text { 7. Government incentives and guidance are important for } \\
\text { shipper cooperation. }\end{array}$ & Agreed with $93 \%$ & \\
\hline \multicolumn{3}{|l|}{ E. SHIPPING MATERIALS } \\
\hline 1.Reduction in packaging materials is very important. & Agreed with $92.3 \%$ & \\
\hline $\begin{array}{l}\text { 2.Improvement in design of packaging materials is very } \\
\text { important. }\end{array}$ & $100 \%$ agreed & \\
\hline $\begin{array}{l}\text { 3.Using materials which are suitable for recycling is very } \\
\text { important. }\end{array}$ & Agreed with $93 \%$ & \\
\hline $\begin{array}{l}\text { 4. Selling the used packaging materials and providing } \\
\text { economic input to the company are very important. }\end{array}$ & $100 \%$ agreed & \\
\hline $\begin{array}{l}\text { 5.Content of agreement between buyers and sellers is very } \\
\text { important. }\end{array}$ & & $\begin{array}{c}85.7 \% \text { (a) } \\
14.3 \% \text { (b) } \\
\text { (Third Round } \\
\text { Applied) }\end{array}$ \\
\hline $\begin{array}{l}\text { 6.Environmental awareness and attitudes of buyers and } \\
\text { sellers are very important. }\end{array}$ & Agreed with $93 \%$ & \\
\hline \multicolumn{3}{|l|}{ F. SHIPPING DESIGN AND COMPLIANCE } \\
\hline $\begin{array}{l}\text { 1.Compliance with the energy efficiency of ship design is } \\
\text { very important. }\end{array}$ & $100 \%$ agreed & \\
\hline $\begin{array}{l}\text { 2.Design of ships must be appropriate for recycling of } \\
\text { waste. }\end{array}$ & $100 \%$ agreed & \\
\hline $\begin{array}{l}\text { 3.Design of ships must be appropriate for disposal of } \\
\text { waste. }\end{array}$ & $100 \%$ agreed & \\
\hline $\begin{array}{l}\text { 4.Design of ships must be appropriate for reuse of } \\
\text { equipment. }\end{array}$ & $100 \%$ agreed & \\
\hline
\end{tabular}




\begin{tabular}{|c|c|c|}
\hline $\begin{array}{l}\text { 5.Design of ships must be appropriate for reducing } \\
\text { environmental negative impacts. }\end{array}$ & $100 \%$ agreed & \\
\hline \begin{tabular}{lllrr} 
G. THE REASONS & FOR ADOPTING AND \\
IMPLEMENTING & \multicolumn{2}{c}{ GREEN } & SHIPPING \\
APPLICATIONS & & & \\
\end{tabular} & & \\
\hline $\begin{array}{l}\text { 1.Presence of the strongly enforced regulatory } \\
\text { environmental requirements is important reason for } \\
\text { adopting and implementing green shipping applications. }\end{array}$ & $100 \%$ agreed & \\
\hline $\begin{array}{l}\text { 2.Presence of the industrial institutionalized norms on } \\
\text { environmental protection are important reason for adopting } \\
\text { and implementing green shipping applications. }\end{array}$ & Agreed with $92.3 \%$ & \\
\hline $\begin{array}{l}\text { 3. Strong environmental requests from customers are } \\
\text { important reason for adopting and implementing green } \\
\text { shipping applications. }\end{array}$ & $100 \%$ agreed & \\
\hline $\begin{array}{l}\text { 4.Firms' request of increase their environmental and } \\
\text { economic performance is important reason for adopting } \\
\text { and implementing green shipping applications. }\end{array}$ & $100 \%$ agreed & \\
\hline $\begin{array}{l}\text { 5. Request of leave a better world for future generations is } \\
\text { important reason for adopting and implementing green } \\
\text { shipping applications. }\end{array}$ & $100 \%$ agreed & \\
\hline \multicolumn{3}{|l|}{$\begin{array}{l}\text { H. DIFFICULTIES OF IMPLEMENTING GREEN } \\
\text { SHIPPING APPLICATIONS }\end{array}$} \\
\hline $\begin{array}{l}\text { 1.Financial problems and costs are important barriers in } \\
\text { implementing green shipping applications. }\end{array}$ & Agreed with $91.7 \%$ & \\
\hline $\begin{array}{l}\text { 2. Lack of education is an important barrier in } \\
\text { implementing green shipping applications. }\end{array}$ & $100 \%$ agreed & \\
\hline $\begin{array}{l}\text { 3.Lack of government incentives and support are important } \\
\text { barriers in implementing green shipping applications. }\end{array}$ & Agreed with $92.3 \%$ & \\
\hline $\begin{array}{l}\text { 4.Creating an additional workload is an important barrier in } \\
\text { implementing green shipping applications. }\end{array}$ & & $\begin{array}{c}76.9 \%(a) \\
23.1 \% \text { (b) } \\
\text { (Third } \\
\text { Round } \\
\text { Applied) }\end{array}$ \\
\hline \multicolumn{3}{|l|}{$\begin{array}{l}\text { I. BENEFITS OF IMPLEMENTING GREEN } \\
\text { SHIPPING APPLICATIONS }\end{array}$} \\
\hline 1.Reduce the average fuel consumption of ships. & $100 \%$ agreed & \\
\hline 2.Reduce the greenhouse gases emissions from ships. & $100 \%$ agreed & \\
\hline 3.Reduce the polluted water released from ships. & Agreed with $93 \%$ & \\
\hline 4.Reduce solid waste from ships. & Agreed with $93 \%$ & \\
\hline 5.Reduce noise pollution from ships & Agreed with $92.3 \%$ & \\
\hline 6.Reduce extinction of marine diversity & $100 \%$ agreed & \\
\hline 7.Increase the environmentally friendly designed ships. & $100 \%$ agreed & \\
\hline $\begin{array}{l}\text { 8.Increase the environmental performance of shipping } \\
\text { firms. }\end{array}$ & $100 \%$ agreed & \\
\hline $\begin{array}{l}\text { 9. Have a positive impact on sustainable economic growth } \\
\text { in the world and Turkey }\end{array}$ & $100 \%$ agreed & \\
\hline 10. Provide a competitive advantage to shipping firms & Agreed with $92.3 \%$ & \\
\hline 11. Have a positive impact on the company image & Agreed with $92.3 \%$ & \\
\hline
\end{tabular}




\begin{tabular}{|l|l|l|}
\hline 12.Increase a customer satisfaction in the shipping sector. & Agreed with $91.7 \%$ & \\
\hline $\begin{array}{l}\text { 13.Have a positive impact on financial performance and } \\
\text { profitability of the shipping firms. }\end{array}$ & Agreed with $91.7 \%$ & \\
\hline $\begin{array}{l}\text { 14.Have a positive impact on relationship between } \\
\text { company and community in the context of social } \\
\text { responsibility. }\end{array}$ & Agreed with $91.7 \%$ & \\
\hline
\end{tabular}

At the end of the second round of Delphi research, the respondents have reached a consensus on all the statements related with company policy and procedures, shipping equipments, shipper cooperation, shipping design and compliance, the reasons for adopting and implementing green shipping applications and benefits of implementing green shipping applications but participants did not reach consensus on some statements related to shipping documents, shipping materials and difficulties of implementing green shipping applications.

In terms of company policy and procedures, results show that managers' awareness and attitudes are very important for green shipping management practices. Managers must believe green shipping management concept both individually and management level. And also there must be a cross departmental support for the green shipping applications. Therefore, there must be a harmony and support among different departments in the company such as operation, technical, finance, human resources and between land and sea personnel.

For shipping documents, it can be stated that, reducing paper consumption is an important way for implementing green shipping concept especially in the offices, but panellists believe that commercial papers are beyond this concept. The statements which are related to e-invoices, payment notifications and bill of ladings have low consensus rate and they entered third round of Delphi research. The requests of original documents, legal and commercial values of these papers and problems of electronic infrastructure can be a reason for these low consensus rates.

Related to shipping equipment, reducing and eco-designing of packaging units are important components of green shipping concept. And also buyer and seller's attitudes and cooperation with equipment suppliers are important factors for using environmentally friendly equipment. Some clauses related to shipping equipmets can be set in the sale or charter agreements in the future.

In the shipper cooperation section, according to the results, shippers must have important role in eco-design cargo handling, environmentally friendly cargo transportation, environmental performance of sector and green distribution and supply chain. And also financial situation of the sector and shippers' environmental awareness and attitudes are important components of shipper cooperation. Government provides some education and encouragement programs such as tax and credit incentives for generating shipper cooperation in the concept of green shipping.

In terms of shipping materials, only one statement which includes content of agreement between buyer and seller entered into third round of Delphi study. According to the results of shipping materials section; reducing packaging materials, environmentally friendly design of packaging materials and environmental awareness and attitudes of buyers and sellers are very important. 
All statements related to shipping design and compliance statements have reached $100 \%$ consensus rate. According to the results, subject of shipping design and compliance is one of the most important components of green shipping applications and ship designs must be suitable for energy efficiency and reducing environmental negative impacts for the green shipping concept.

According to results of Adopting and Implementing Reasons of Green Shipping Applications, environmental regulations, industrial norms, customers' requests, increasing economic and environmental performance and request of leaving a better world for future generations are important reasons for adopting and implementing green shipping applications.

In the section of Difficulties of Implementing Green Shipping Applications, the results showed that lack of education is one of the most important barriers for implementing green shipping applications. To solve these problem, firstly environmental awareness must be instilled from childhood. In terms of shipping firms, relevant trainings must be provided for seamen before voyages. Financial problems and lack of government incentives and support are other important barriers for implementing green shipping applications. Only one statement has not reached a consensus which is related to whether green shipping practices create an additional workload or not. And lastly, according to the answers related to benefits of implementing green shipping applications, green shipping applications can reduce the average fuel consumption of ships and negative environmental impacts of ships. In addition, green shipping applications can increase the environmentally friendly designed ships, environmental performance of shipping firms and sustainable economic growth in the world and Turkey. And also green shipping applications provide a competitive advantage, positive image, customer satisfaction, positive impact on financial performance and profitability and positive impact on relationship between company and community in the context of social responsibility. Green shipping applications first of all increase the company's compliance with international standards and the make the company greener and more global. Therefore, company's financial performance, competitive power and image can be increased by implementing green shipping applications.

\subsection{Results of the Third Round of the Delphi Research}

After the second round of Delphi research, the five statements without consensus according to the answers of the panellists in the second round have been used to construct the third round Delphi survey. 11 participants responded to the third round of Delphi survey. And also the panellists were asked to write the reasons for participating or not in each question in this round. APMO cut-off percentage rate for the third round Delphi survey has been found $94.5 \%$ according to the following equation and information in Table 4.

$$
\mathrm{APMO}=\frac{\text { Majority Agreements }+ \text { Majority Disagreements }}{\sum \text { Opinions Expressed }} \quad 94.5=\frac{33+19}{55}
$$


Table 4: Summary Results of Third Round of the Delphi Research

\begin{tabular}{|l|l|}
\hline Majority Agreements & 33 \\
\hline Majority Disagreements & 19 \\
\hline Total Opinion Expressed & 55 \\
\hline Average Percent of Majority Opinions & $94.5 \%$ \\
\hline Number of Statements Reaching Consensus & 0 \\
\hline Low Consensus (70-79\%) & 1 \\
\hline Medium Consensus (80-89\%) & 1 \\
\hline High Consensus (90-100\%) & 0 \\
\hline Number of Statements over 70\% Consensus & 2 \\
\hline
\end{tabular}

Table 5: Results of the Third Round of the Delphi Research

\begin{tabular}{|c|c|c|}
\hline \multirow[t]{2}{*}{ STATEMENTS } & \multicolumn{2}{|c|}{ TOTAL RESULTS } \\
\hline & Consensus & Non Consensus \\
\hline $\begin{array}{l}\text { 1. Within the green shipping management practices, } \\
\text { concerning the shipping documents, to reduce paper } \\
\text { consumption and waste, invoices should be prepared, } \\
\text { signed and stored electronically. }\end{array}$ & & $\begin{array}{l}60.0 \% \text { (a) } \\
40.0 \% \text { (d) }\end{array}$ \\
\hline $\begin{array}{l}\text { 2. Within the green shipping management practices, } \\
\text { concerning the shipping documents, to reduce paper } \\
\text { consumption and waste, payment notifications should be } \\
\text { prepared, signed and stored electronically. }\end{array}$ & & $\begin{array}{l}50.0 \%(a) \\
50.0 \%(d\end{array}$ \\
\hline $\begin{array}{l}\text { 3. Within the green shipping management practices, } \\
\text { concerning the shipping documents, to reduce paper } \\
\text { consumption and waste, bill of ladings should be } \\
\text { prepared, signed and stored electronically. }\end{array}$ & & $\begin{array}{l}50.0 \%(a) \\
50.0 \%(d\end{array}$ \\
\hline $\begin{array}{l}\text { 4. Within the green shipping management practices, } \\
\text { concerning the shipping materials, reducing and } \\
\text { environmentally friendly designing of shipping and } \\
\text { packaging materials are very important. }\end{array}$ & & $\begin{array}{l}81.8 \% \text { (a) } \\
18.2 \% \text { (d }\end{array}$ \\
\hline $\begin{array}{l}\text { 5. Full compliance with environmental standards and } \\
\text { regulations is a requirement in the maritime sector. This } \\
\text { situation can be perceived as an additional burden by the } \\
\text { companies and it can be seen as a challenge for greener } \\
\text { maritime operations. }\end{array}$ & & $\begin{array}{l}72.7 \% \text { (a) } \\
27.3 \% \text { (d }\end{array}$ \\
\hline
\end{tabular}

According to the results, there is no consensus in the third round of Delphi study. The first three statements related to shipping documents not reached a consensus with the agreement rates of $60 \%, 50 \%$ and $50 \%$ respectively. The fourth statement related to shipping materials has not reached a consensus with the rate of $81.8 \%$. The last statement, which is related to difficulties of green shipping applications has not been reached a consensus with the rate of $72.7 \%$. Despite the benefits, some participants perceived green shipping applications as an additional burden by the companies.

Shipping documentation dimension of green shipping practices which includes the first three statements of the third round of Delphi study aims to reduce use of paper, 
cutting down paperwork, simplify the shipping processes and decrease the possibility of errors. According to the comments of the panellists, they accept the advantages of electronic solutions but because of the infrastructure and validity problems they have some hesitations related to this issue. For the fourth statement which is related to reducing and environmentally friendly designing of shipping and packaging materials, generally participants have not seen negative impact on this issue. But two participants stated that, in this subject, opinions and attitudes of cargo owners and charterers are more important than ship owners and also this situation can lead to disruption in trade. Therefore, they can be reasons for disagreement in this statement. And the fifth statement, which includes compliance with environmental standards and regulations is a requirement in the maritime sector, but it can be perceived as an additional burden by the companies and it can be seen as a challenge for greener maritime operations and has not reached a consensus. According to the comments of the panellists, the rules and regulations put a strain on shipping firms in terms of financial and operational difficulties. In the poor market conditions this situation can be perceived as an additional burden by the ship owners. And also, unless environmentalism has a place in society culture, rules and regulations will not achieve success. This situation can be reasons for concensus. But, some panellists believed that, if the ship owners are not enforced by the rules and regulations for the greener operations, progress related to this subject is not possible in the shipping industry. In addition, in first stage these regulations can be seen as a burden by the companies but in the long turn, they will give positive contribution to the firms. These opinions of panellists can be reasons for disagreement in this statement.

\section{Conclusion}

Maritime transport which includes all the cargo movement activities to, from and between key actors of transport chains is the most preferable transportation mode owing to large carrying capacity without overdraft restrictions, reliability and low cost. Compared to other transport modes, maritime transport has had a relatively green image but still is a main participator to global ecological problems.

Main aim of the study is to examine the attitudes of Turkish shipowning companies towards green shipping applications. To meet the aim of the research, the three round Delphi survey was implemented. At the end of the third round of Delphi research, the respondents have reached a consensus statements on company policy and procedures, shipping equipments, shipper cooperation, shipping design and compliance, the reasons for adopting and implementing green shipping applications and benefits of implementing green shipping applications but the participants have not reached consensus on some statements related to shipping documents, shipping materials and difficulties of implementing green shipping applications.

When examined the participation rates of all sections concerning with green shipping practices dimensions, the results were found consistent with the literature. For example, in the study from Chiu et al. (2012) mean values of environmental protection, education on green management and ship technology improvement are relatively high. In the study of Lirn et al., (2014), greener policy has a direct and positive impact on both the greener ships and the greener suppliers elements. Similarly, in this study respondents have stated the importance of green policies in the first round of Delphi study, because greener policy is the main element of creating vision or culture for environmental protection and sustainability in a shipping firm. And also green ships and 
company policy and procedure section statements in the second round of Delphi study have had a high consensus rates.

In the study of Lai et al., (2013); shipping equipment and shipping design and compliance factors have the highest values for green shipping practices. Shipping equipment is concerned with the use of environmentally friendly shipping equipment and facilities and shipping design and compliance is concerned with minimizing the life-cycle environmental damage of shipping activities by taking measures in compliance with regulatory requirements. These two dimensions are essential for green shipping concept. Alike, in this study, all of the shipping design and compliance section statements have $100 \%$ consensus rates and all of the shipping equipment statements similarly have high consensus rates. And also in the study of Lun et al., (2015), shipping documentation, company policy and procedure, shipping materials and shipping design and compliance sections have high values but shipping firms were found relatively weak in the practices of shipper cooperation and shipping equipment. In this study one statement of each practices related to shipper cooperation and shipping equipment had 93\% and $92.3 \%$ consensus rates but because of high consensus rate, they have not entered in the third round of Delphi study. It means that, using environmentally friendly shipping equipment and facilities and cooperating with shippers on environmental objectives are substantial for implementing green shipping applications. But one participant denied the importance of government incentives and guidance for shipper cooperation and again one participant denied the importance of the content of agreement for selecting equipment which are used.

Unlike other studies in green shipping literature, in this study shipping documentation section statements which are related to reducing the use of paper and simplifying the shipping processes have weak consensus rates because of the deficiencies of electronic infrastructure, possibilities of fraud, difficulties of preparing the documents and invoices in the ports and ships and necessities of filling commercial papers for the audits. And also different from other studies, green shipping dimensions, adopting and implementing reasons, difficulties and benefits were examined together in this study.

At the end of the research, the outcomes demonstrate that the exercising of green shipping concept is in an initial phase but with the rise in freight rates and increase in the government incentives and guidelines, impression was obtained that Turkish shipping companies can implement much greener operations.

The study and findings might be helpful for managers of shipping sector to familiarizing the concept or development of environmental protection and green shipping applications. They can use this concept to balance the shipping firms' productivity with environmental performance and perform regular reviews of green shipping implementation to determine considerations for persistent developments. Main limitations of the study were difficulties in reaching the managers working in Turkish shipowning companies and long period of Delphi research. For future researches, examining factors that influence the adoption of green shipping practices, involving effects of firm's own environmental strategies and increasing the sample size are suggested. 


\section{References}

Bijwaard, G. E., Knapp, S. (2009). "Analysis of ship life cycles - the impact of economic cycles and ship inspections". Marine Policy, 33(2), 350-369.

Brett, V., Roe, M. (2010). "The potential for the clustering of the maritime transport sector in the Greater Dublin Region". Maritime Policy \& Managment, 37(1), 116.

Casaca, A.C.P., Durate, L.F., Lun, Y.H.V. (2011). "Shipping and transport logistics in a changing economy". International Journal of Shipping and Transport Logistics, 3 (4), 345-348.

Chang, Y. T., Danao, D. (2017). "Green shipping practices of shipping firms". Sustainability, 9(5), 829.

Chiu, R. H., Huang, Y. J. and Ting, S. C. (2012). "Factors to Influence Green Shipping Actions Taken by Carriers".

Dalkey, N., Helmer, O. (1963). "An experimental application of the Delphi Method to the use of experts". Management Science, 9(3), 458-467.

Hon, C. K., Chan, A. P., Yam, M. C. (2011). "Empirical study to investigate the difficulties of implementing safety practices in the repair and maintenance sector in Hong Kong". Journal of Construction Engineering and Management. 138(7), 877-884.

Hsu, C. C., Sandford, B. A. (2007). "The Delphi technique: Making sense of consensus". Practical Assessment, Research \& Evaluation, 12(10), 1-8.

IMO. (2013). "World Maritime Day- A Concept of a Sustainable Maritime Transportation System. Retrieved from http://www.imo.org/en/About/Events/WorldMaritimeDay/WMD2013/Docume nts/CONCEPT\%20OF\%20\%20SUSTAINABLE\%20MARITIME\%20TRANS PORT\%20SYSTEM.pdf

Kapoor, P. (1987). "Systems approach to documentary maritime fraud". (Unpublished Doctoral Dissertation) Plymouth Polytechnic, Plymouth, 1987.

Ke, Y., Wang, S., Chan, A. P., Cheung, E. (2011). "Understanding the risks in China's PPP projects: Ranking of their probability and consequence". Engineering, Construction and Architectural Management, 18(5), 481-496.

Keeney, S., Hasson, F. McKenna, H. (2011). "Front matter, in the Delphi Technique in nursing and health research". Oxford, UK: Wiley-Blackwell.

Lai, K. H., Lun, V. Y., Wong, C. W., Cheng, T. C. E. (2011). “Green shipping practices in the shipping industry: Conceptualization, adoption and implications". Resources, Conservation and Recycling, 55(6), 631-638.

Lai, K. H., Lun, Y. V., Wong, C. W, Cheng, T. C. E. (2013). "Measures for evaluating green shipping practices implementation". International Journal of Shipping and Transport Logistics, 5(2), 217-235. 
Lam, J. S. L., Lai, K. H. (2015). "Developing environmental sustainability by ANPQFD approach: the case of shipping operations". Journal of Cleaner Production, 105, 275-284.

Linstone, H. A., Turoff, M. (Eds.). (1975). "The Delphi method: Techniques and applications (Vol. 29)". Reading, MA: Addison-Wesley

Lirn, T. C., Lin, H. W., Shang, K. C. (2014). "Green shipping management capability and firm performance in the container shipping industry". Maritime Policy \& Managment, 41(2), 159-175.

Lun, V. Y., Marlow, P. (2011). "The impact of capacity on firm performance: A study of the liner shipping industry". International Journal of Shipping and Transport Logistics. 3(1), 57-71.

Lun, Y. V., Lai, K. H., Cheng, T. E. (2013). "An evaluation of green shipping networks to minimize external cost in the Pearl River Delta region". Technological Forecasting and Social Change, 80(2), 320-328.

Lun, Y. V., Lai, K. H., Wong, C. W., Cheng, T. C. E. (2014). "Green shipping practices and firm performance". Maritime Policy \& Management, 41(2), 134-148.

Lun, Y. V., Lai, K. H., Wong, C. W., Cheng, T. E. (2015). "Greening and performance relativity: An application in the shipping industry". Computers \& Operations Research. 54, 295-301.

Mander, S. (2017). "Slow Steaming and a new dawn for wind propulsion: A multi-level analysis of two low carbon shipping transitions". Marine Policy. 75, 210-216.

Ren, J., Lützen, M. (2017). "Selection of sustainable alternative energy source for shipping: Multi-criteria decision making under incomplete information". Renewable and Sustainable Energy Reviews, 74, 1003-1019.

Skulmoski, G. J., Hartman, F. T., Krahn, J. (2007). “The Delphi method for graduate research". Journal of Information Technology Education, 6, 1-21

von der Gracht, H. A. (2012). "Consensus measurement in Delphi studies. Technological Forecasting and Social Change”. 79(8), 1525-1536.

Zhang, F., Ng, C. T., Tang, G., Cheng, T. C. E., Lun, Y. H. V. (2011). "Inverse scheduling: Applications in shipping”. International Journal of Shipping and Transport Logistics, 3(3), 312-322. 